Santa Clara University

Scholar Commons

English

College of Arts \& Sciences

$10-2012$

\title{
Hrotsvit's Apostolic Mission: Prefaces, Dedications, and Other Addresses to Readers
}

Phyllis Brown

SantaClara University, pbrown@scu.edu

Follow this and additional works at: http://scholarcommons.scu.edu/engl

Part of the English Language and Literature Commons

\section{Recommended Citation}

Brown, Phyllis "Hrotsvit's Apostolic Mission: Prefaces, Dedications, and Other Addresses to Readers." In Hrotsvit of Gandersheim (fl. 960): Contextual and Interpretive Approaches. Ed. Phyllis R. Brown and Stephen L. Wailes. Brill's Companions to the Christian Tradition 34. Brill, 2012. 235-64.

Copyright 2012 Brill. All Rights Reserved. http://dx.doi.org/10.1163/9789004234390

This Book Chapter is brought to you for free and open access by the College of Arts \& Sciences at Scholar Commons. It has been accepted for inclusion in English by an authorized administrator of Scholar Commons. For more information, please contact rscroggin@scu.edu. 


\title{
HROTSVIT'S APOSTOLIC MISSION: \\ PREFACES, DEDICATIONS, AND OTHER ADDRESSES TO READERS
}

\author{
Phyllis R. Brown
}

\section{Hrotsvit's Apostolic Mission}

The most complete manuscript of Hrotsvit's writings, Bavarian State Library Clm 14485 (the Munich codex), includes prefaces, dedications, and other addresses to readers in which Hrotsvit names herself and provides information about her education, writing practices, and purposes. If this manuscript had not survived, we might have some of her plays and poems extant in other manuscripts, but we would know little or nothing about Hrotsvit, and we would likely not be able to imagine that such a scholar and writer could have existed. ${ }^{1}$ By naming and identifying herself as an author and addressing readers in the first-person, not only in the prefatory texts but also within the poems, Hrotsvit presents herself as an important actor throughout the manuscript and creates significant parallels between her actions and those of the characters in her poems and plays. She also invites readers to see parallels between herself, her characters, Christ's apostles, and John the Baptizer. Furthermore, in the world created by Hrotsvit's writings, all words and actions are always relevant to one of the main themes of her poems and plays: conversion. Readers, writers, and characters in her writing have two choices (which in a sense is one choice): they can turn toward God and be saved by grace, or they can turn away from God. Some, like the apostles, choose in response to Christ's mandate; others, like John the Baptizer, are pre-cursors of Christ. For all, whether already Christian or pagan, conversion involves the Augustinian "turning" of the mind and will toward God. And all have a shared responsibility not only to welcome grace "as a free gift that elevates us to a new and unmerited level of existence"2 but also to use their God-given talents to contribute to the redemption of the world.

\footnotetext{
1 See Walter Berschin's account of the surviving manuscripts in the introduction to his edition and, translated into English, in "Hrotsvit and her Works," in this volume.

2 Richard P. McBrien, Catholicism, new edition (San Francisco, 1994), p. 169.
} 
While the idea that the gifts of free will and grace require all humans to take responsibility for their daily actions is central to Catholic teaching, Hrotsvit's writings present the theological ideas in especially powerful ways. As Stephen Wailes argues in Spirituality and Politics in the Works of Hrotsvit of Gandersheim, Hrotsvit dramatizes in her poems and plays "the age of Grace and of apostleship, the age in which she and her fellows lived. In this age, all Christians must serve God as they are particularly able; such service may include (in the author's case) the activity of literary composition."3 In other words, Hrotsvit's writings emphasize that the responsibility Christ assigns to his disciples applies to every Christian. For example, in Hrotsvit's poem about the Ascension, Christ says (in a paraphrase of Matt. 28:19 and John 20:2):

As the Father has sent Me forth, His dearly beloved Son, into the world, so do I also send you, my cherished friends. But you, going speedily to all nations, teach them the commandments of eternal life, purifying forthwith with the sacred water those who believe in the name of the Father, and likewise of the Son, and also of the Holy Ghost, that thus they may put off the stains of ancient guilt. ${ }^{4}$

While in the Bible Christ addresses his 11 disciples, Hrotsvit's narrative introduction of Christ's speech invites readers to imagine themselves as among the "cherished friends" whom Christ addresses before his ascension. Her action and mode of recounting Christ's speech in her poem effectively broadens the audience of "cherished friends" — and by extension the task with which they are charged-to include all of Hrotsvit's readers.

Hrotsvit was not alone in understanding the apostolic mission to extend to all Christians. For instance, Alan Thacker has shown that the Venerable Bede's "later writings were permeated with a vision of reform in church and society which was to leave its mark on more than his own generation." Thacker demonstrates that Bede "was much preoccupied with the role of those whom he variously called the spirituales magistri, the sancti praedicatores, the rectores or doctors ecclesiae" and that Bede understood preaching to have "a pre-eminent, even a sacramental, significance," concerned not only with conversion of pagans but also with "promoting the

\footnotetext{
3 Wailes, Spirituality, p. 55 .

4 Wiegand, p. 75; "Ut pater in mundum me promisit sibi carum, / Sic ego mitto meos dilectos vosmet amicos. / At vos in gentes citius cunctas abeuntes / Illas perpetuę vitę mandata docete / Credentes sacra purgantes ocius unda / In patris et nati pariter quoque flaminis almi / Nomine, quo veteris deponant crimina sordis," pp. 36-37, lines 23-29. All Latin citations to Hrotsvit's works are from Berschin, Opera.
} 
moral well-being or theological understanding of the faithful." According to Thacker, Bede's teachers and preachers were the spiritual leaders and guides of the people of God, the successors of the prophets and apostles, to whose ordo they belonged and whose role they fulfilled in the contemporary Church. ${ }^{5}$ Significantly, Bede "even envisaged women preachers" in his Homilies, De Templo, and In Ezram. ${ }^{6}$ Equally significant, Hrotsvit uses the verb "to preach" (praedicare) not only to denote her action as a writer but also to identify herself with the saints. For example, in the Preface to the Plays, she concludes her address to hypothetical critics who might charge her with presumption for imitating the classical playwright Terence by specifying that she knows herself not to be "the equal of those who by far are my betters in learning," not even to be in that category of "these scholars' pupils." Rather, she writes:

this alone I strive for with humble and devoted heart / - even if aptitude is lacking on my part - / that I may return the gift I received to its Giver again. / For I am not such a lover of myself nor so vain / that in order to avoid censure I would refrain / from preaching Christ's glory and strength as it works through His saints to the extent He grants me the ability to do so. ${ }^{7}$

In the guise of this humility topos, articulating her unwillingness to compare herself positively with even the least of her critics' pupils, Hrotsvit suggests that her critics may fall into the category of Christians who turn away from God, toward Terence's plays, which they find stylistically superior, while she, "with a humble and devoted heart," uses her God-given gifts to preach "Christ's glory and strength as it works through His saints."

5 Alan Thacker, "Bede's Ideal of Reform," Ideal and Reality in Frankish and AngloSaxon Society: Studies Presented to J.M. Wallace-Hadrill, ed. Patrick Wormald with Donald Bullough and Roger Collins (Oxford, 1983), p. 130. R.A. Markus' “Gregory the Great's Pagans," in Belief and Culture in the Middle Ages: Studies Presented to Mayr-Harting, ed. Richard Gameson and Henrietta Leyser (Oxford, 2001), pp. 23-34, addresses the issue of preaching in later periods when the need for conversion is among baptized Christians. See especially pp. 33-34. The 1oth century witnessed many reform-minded monks and priests, such as Abbo in France and Aelfric and Wulfstan in England.

6 Thacker, "Bede's Ideal of Reform," p. 131.

7 Wilson, Plays, pp. 3-4; Non enim dubito mihi ab aliquibus obici $\cdot$ quod huius vilitas dictationis multo inferior $\cdot$ multo contractior $\cdot$ penitusque dissimilis eius quem proponebam imitari - sit sententiis . Concedo. Ipsis tamen denuncio · me in hoc iure reprehendi no posse $\cdot$ quasi his vellem abusive assimilari - qui mei inerciam $\cdot$ longe praecesserunt in scientia sublimiori · Nec enim tantę sum iactantię · ut vel extremis me presumam conferre auctorum alumnis $\cdot$ sed hoc solum nitor $\cdot$ ut licet nullatenus valeam apte $\cdot$ supplici tamen mentis devocione acceptum in datorem retorqueam ingenium - Ideoque non sum adeo amatrix mei · ut pro virtanda reprehensione Christi qui in sanctis operator virtutem quocumque ipse dabit posse cessem praedicare ', p. 133, lines $3^{-16}$. 
Hrotsvit seems to align herself with 1oth-century monastic reformers even as her message emphasizes an equality of women not present in the agenda of some reformers. ${ }^{8}$

While Hrotsvit is particularly specific about her role as a preacher in the Preface to the Plays, in the plays themselves she never speaks in her own voice. Rather, both first-person narration and third-person narration are supplanted by dialogue. Frequently, however, that dialogue addresses the theme of conversion. Scholarly interest in the plays since the first print edition in 1501, in which Conrad Celtis reordered Hrotsvit's writing, placing the plays before the hagiographic poems, suggests her experiment in dramatizing the theme of conversion at the very least has engaged the attention and interest of her readers. Other essays in this volume, especially Michael Zampelli's, explore some of the ways in which the plays allow Hrotsvit to preach "Christ's glory and strength as it works through His saints." This essay will focus on ways her first-person addresses to readers both prepare for and participate in her preaching, whether it is specifically about Christ's glory or about conversion, the human responsibility to turn toward Christ and God and contribute to the redemption of the world.

\section{Three Kinds of Addresses}

Hrotsvit addresses her readers in a variety of ways. Five of her prose addresses have received the most critical attention. Three of these-the First Preface, the Preface to the Plays, and a brief discussion of sources and authority placed between what she calls Book One and Book Twoare addressed to readers in general. The fourth prose address, called a letter in the manuscript, names her learned patrons as audience; the fifth names her abbess Gerberga as audience. In the two prose addresses to very specific audiences-her learned patrons and Gerberga-Hrotsvit also names herself as author, giving both the quality of a letter.

Hrotsvit's poetic addresses to readers have received less critical attention than the prose addresses, yet they speak eloquently about Hrotsvit's sense of herself as an author and also contribute to the overarching theme of Christian responsibility. The first instance is a 12-line poem in

\footnotetext{
8 Helene Scheck devotes two chapters to Hrotsvit's career in the context of monastic reforms in Reform and Resistance: Formations of Female Subjectivity in Early Medieval Ecclesiastical Culture (Albany, 2008).
} 
elegiac distichs addressed to Gerberga, placed on the same manuscript page as the concluding lines of the first preface. Hrotsvit addresses Gerberga again, with six elegiac distichs, between the end of "Theophilus" and the beginning of "Basilius." A ten-line address to readers in the same verse form follows immediately afterward, on the same manuscript page. Both of these poems continue themes introduced in the first preface and developed in the hagiographic poems. Hrotsvit also addresses Otto I and Otto II in poems placed between the prose address to Gerberga and the beginning of the Gesta. Although not included in the Munich manuscript, a six-line prefatory poem in hexameters addresses the readers of the Primordia, which only survives in post-medieval manuscripts.

Occasional authorial insertions, often in the form of prayers, in the narrative poems have received even less critical attention in discussions of Hrotsvit's prefaces and dedications. These insertions include the first four instances of Hrotsvit's naming herself in the manuscript: in a prayer addressed to Mary placed between the title of the first narrative poem, Maria, and the beginning of the narrative; at the end of Ascensio, in a request for readers to "say with a pitying heart: 'Gentle King, have mercy on poor Hrotsvitha and spare her, and grant that she may with grace from heaven continue to sing Thy divine praises, who in verse has set forth Thy marvels' "; 9 in an 18-line prayer on the following manuscript page, introducing Gongolfus; and in a prayer to Pelagius, the martyr celebrated in Pelagius, in which she asks for his gracious regard and assistance so that she will be able to sing worthily of his triumphs and fame. Other authorial insertions draw readers' attention to the difficulty of articulating the wondrous events and praising adequately the characters of her poems. Yet others invite readers to join her in prayer and songs of praise and/or suggest parallels between actions and beliefs of her characters and of herself as a Christian and a writer.

\section{The Prose Addresses}

Less well-known than the First Preface, which introduces what Hrotsvit calls Book One and the manuscript collection of her works as a whole, and the Preface to the Plays, introducing Book Two, is a briefer prose address.

\footnotetext{
9 Wiegand, p. 83; Haec quicumque legat, miseranti pectore dicat: / 'Rex pie, Hrotsvithe parcens Miserere miselle / Et fac divinis persistere caelitus odis / Hanc, quę laudando cecinit tua facta stupenda, p. 41, lines $147-50$.
} 
This seems an appropriate place to begin because it is the first of only two prefatory texts in the Munich manuscript with a title or heading and because it provides information about the structure of the manuscript. The heading or title reads, "The first book ends; the second begins, ordered in a dramatic series." ${ }^{10}$ After this heading, eight manuscript lines of prose distinguish between "this little work," the collection of dramas, and "the former one," the collection of sacred stories, and assert that she has drawn on written authorities as sources of information for all but one poem:

All the material of this little work as well as the former one I have taken from ancient books written under the names of certain authors, except for the passion written above of St Pelagius. A certain inhabitant of the city in which he suffered related to me the history of his martyrdom. He attested that he saw the most beautiful of men and that he knew the outcome of the affair truly. Hence if I have included anything of falsity in relating each account, I have not deceived on my own account but incautiously was imitating the deceived ones. ${ }^{11}$

These lines extend the discussion of sources introduced in the First Preface, where Hrotsvit writes that she learned after she completed Maria that parts of her poem were based on written sources considered apocryphal:

When, however, the charge is raised / - or at least by some so appraised-I that parts of this work's discourses / are based on apocryphal sources, / then I must reply / and hereby testify / that it was not a misdeed of presumption / but the innocent error of flawed assumption, / because when I first started to weave the strands of these works, I was not aware that some of my sources met with doubt; / and when I did find this out, / I still decided not to suppress them because what appears to be false today / may perhaps be proven true another day. ${ }^{12}$

\footnotetext{
10 My translation; Explicit liber primus - Incipit secundus dramatica serie contextus, p. 131.

11 My translation; Huius omnem materiam sicut et prioris opusculi sumsi ab antiquis libris sub certis auctorum nominibus conscriptis · excepta superius scripta passione sancti Pelagii · cuius seriem martirii quidam eiusdem in qua passus est indigena civitatis mihi exposuit · qui ipsum pulcherrimum virorum se vidisse et exitum rei attestatus est veraciter agnovisse - Unde si quid in utroque falsitatis dictando comprehendi - non ex meo fefelli sed fallentes incaute imitate fui, p. 131, lines 1-9.

12 Wilson, Florilegium, p. 19; Si autem obicitur quod quedam huius operis · iuxta quorundam estimationem sumpta sint ex apocrifis · non est crimen presumptionis inique sed error ignorantię quia quando huius stamen seriei · ceperam ordiri · ignoravi dubia esse in quibus disposui laborare - At ubi recognovi pessumdare detrectavi - quia quod videtur falsitas · forsan probabitur esse veritas, p. 1, lines 10-16.
} 
This brief prose text between the sacred stories and the plays also anticipates attention to sources and authority in the texts introducing the Gesta. Hrotsvit recognizes the difficulty in distinguishing truth from falsehood, and, like Bede, she understands the importance of acknowledging and evaluating sources. Yet she trusts her own judgment, whether her source is considered apocryphal or is the oral account of a witness, and she seems aware that she herself may be an authority for writers in the future.

Hrotsvit also draws attention to the absence of authority-other than that from God-in her conclusion to the First Preface, when she writes:

Therefore, reader, whoever you may be, / if you live rightly / and are wise in God, don't withhold the favor of your benign goodwill from these flawed pages / that are not built on the authorities of precedent or the wisdom of sages. / If, by chance, you find here something well wrought, give all the credit to God's grafting / but for all the flaws, assign the blame to my poor crafting. ${ }^{13}$

Embedded in the humility topos is a rather extraordinary statement of her originality.

The First Preface, the Preface to the Plays, the "Epistle," and the Third Address to Gerberga that introduces the Gesta have received considerable scholarly attention, often with a focus on their value as sources of information about Hrotsvit and the cultural milieu in which she thrived. Indeed, nearly everything we know about Hrotsvit's life, education, and intentions as a writer has been gleaned from Hrotsvit's addresses to readers. For example, in her First Preface, which seems to address all Catholics, she names two teachers, Rikkardis and her abbess, Gerberga, who was younger than Hrotsvit "but as befits the Emperor's niece, more advanced in learning." Hrotsvit also specifies that Gerberga introduced her to "the works of those writers whom she herself studied with learned men."14 In her "Epistle," Hrotsvit refers to the difficulty of continuing her study independently after her formal education ended; yet other evidence in the manuscript indicates extensive familiarity with the Bible, exegetical writings (especially commentaries of Augustine, Gregory, Alcuin, and Hrabanus Maurus), other ecclesiastical writers (such as Tertullian, Venantius

13 Wilson, Florilegium, p. 20; Unde quicumque lector si recte et secundum deum sapias . egenti paginę - que nullius praeceptoris munitur auctoritate opem tue rectitudinis ne pigriteris abhibere deo videlicet si quid forte probetur recte compositum, p. 2, lines 23-26.

14 Wilson, Florilegium, p. 19; quę aetate minor - sed ut imperialem decebat neptem . scientia provectior aliquot auctores quos ipsa prior a sapientissimis didicit me admodum pie erudivit •, p. 2, lines 9-12. 
Fortunatus, and Cassian), hagiography, pagan and Christian writers (such as Terence, the only one she names, Vergil, Ovid, Seneca, Prudentius, Sedulius, Boethius, and Aldhelm), grammatical and metrical reference books, and pedagogical commentaries and glossaries. Thus readers must be wary of a too literal reading of Hrotsvit's prose addresses, which Katharina Wilson has shown to be richly rhetorical. ${ }^{15}$

In the prose prefaces Hrotsvit also provides details that guide the dating of the sacred stories, plays, and historical poems. For example, because Hrotsvit identifies her abbess, Gerberga II, as niece of the emperor (imperialem neptem) in the First Preface, scholars conclude that the book of sacred stories was completed after 962, when Otto I was crowned emperor. However, the First Preface may have been written some time after the sacred stories themselves were completed. ${ }^{16}$ Similarly, Hrotsvit must have completed the Third Address to Gerberga, which introduces the Gesta, before 968, since she specifies that she awaits Gerberga's judgment and the judgment of Wilhelm, Archbishop of Mainz, who died in 968.17

In Hrotsvit's addresses to her readers, scholars have also discerned information about her writing practices and awareness of audience expectations. For example, in the First Preface, Hrotsvit informs her readers that she initially worked in secret because she feared she might otherwise be forced to stop. Scholars frequently note that Hrotsvit introduces herself to her readers in the First Preface by emphasizing her initial lack of confidence, her rusticity, and her struggle "to put together a text-be its merit ever so slight."18 She articulates her fears that critics will focus on flaws in her writing, "in the handling of meter, style, and diction," and in her choice of sources, and that they will consider her presumptuous. ${ }^{19}$ She also informs her readers that she destroyed earlier drafts when she was not satisfied with her work, and read all the source material she could gather at Gandersheim.

Hrotsvit's open admission of her fears and insecurities in the First Preface likely had the intended rhetorical effect: as various Greek and Roman

\footnotetext{
15 Wilson, Ethics, pp. 3-27.

16 If the First Preface is understood as introducing a three-part "little book" — the entire manuscript - as well as the sacred stories, this date is less significant.

17 See Walter Berschin's account of the dates in the Preface to his edition of Hrotsvit's Opera Omnia, pp. vii-x, translated in "Hrotsvit and her Works," in this volume.

18 Wilson, Florilegium, p. 1; iuxta meum posse licet minime necessarium aliquem tamen conficere textum, p. 2, lines $3-4$.

19 Wilson, Florilegium, p. 1; in dinoscendis syllabarum naturis verum etiam in dictionibus componendis, p. 1, lines 6-7.
} 
authorities on rhetoric explain, the aim of a preface is to gain the audience's attention and good will. Hrotsvit draws attention to supposed inadequacies before any reader can do so and asks for a sympathetic reading that takes into account the difficulty of the writing tasks as well as the purposes and motivations for writing. As Katharina Wilson notes, "she repeatedly asks her readers for stylistic correction instead of censure." 20 In doing so, Hrotsvit not only uses the rhetorical strategies she has been taught; she also draws the attention of similarly educated readers to her rhetorical knowledge and the skill with which she weaves the rhetorical formulas through her writings. Thus Hrotsvit's First Preface not only provides tantalizing details about her education; the writing itself provides ample evidence that she has studied rhetoric as well as "the handling of meter, style, and diction" and that she can put all she has learned into practice. That evidence is confirmed and amplified by all the writing that follows in the manuscript.

The First Preface also introduces Hrotsvit's purpose in writing. The expression of her purpose suggests the ordering mind of an interpreter who sees the Bible, biblical exegesis, and Christian literature as exemplars for her own creative and interpretive writing. Hrotsvit explains:

However difficult and arduous and complex / metrical composition may appear for the fragile female sex, / I, persisting / with no one assisting / still put together my poems in this little work / not relying on my own powers and talents as a clerk / but always trusting in heavenly grace's aid / for which I prayed, / and I chose to sing them in the dactylic mode / so that my talent, however tiny, should not erode, / that it should not lie dormant in my heart's recesses and be destroyed by slothful neglect's corrosion, / but that, struck by the mallet of eager devotion, / it bring forth a tiny little sound of divine praise / and, thus, if for no other purpose but for this case, / it may be transformed into an instrument of some utility / regardless of the limits of my ability. ${ }^{21}$

Hrotsvit sees herself as enacting the lesson of Christ's parable of the talents (Matt 25:14-30) in her own life and writings: her talents will not

20 Wilson, Ethics, p. 4. Wilson provides a thorough and illuminating discussion of Hrotsvit's uses of classical rhetorical strategies in the prefaces, pp. $3^{-16}$.

21 Wilson, Florilegium, pp. 19-20; Quamvis etiam metrica modulatio femineę fragilitati difficilis videatur et ardua - solo tamen semper miserentis supernę gratię auxilio non propriis viribus confisa - huius carmina opusculi dactilicis modulis succinere apposui . ne crediti talentum ingenioli sub obscuro torpens pectoris < antro > rubigine neglegentię exterminaretur $\cdot$ sed sedule malleo devotionis percussum aliquantulum divine laudationis referret tinnitum - quo si occasio non daretur negociando aliud lucrari · ipsum tamen in aliquod saltim extreme utilitatis transformaretur instrumentum, p. 2, lines 13-22. 
"lie dormant" or be buried and useless as is the talent of the slothful servant in Matthew; rather, "trusting in heavenly grace's aid," she will use her talents to create songs of divine praise. Wilson notes that Hrotsvit's "first metaphor of poetic creation" extends Christ's command that his followers spread his ideas to her own work and specifies "that it is God's gift of grace infusing the artist which makes his or her work persuasive."22

The Preface to the Plays provides additional information about Hrotsvit's writing practices and her purposes, and these details often clarify meaning that is less obvious in the First Preface. She begins with one of the best known passages of her writing:

Many Catholics one may find, / and we are also guilty of charges of this kind, / who for the beauty of their eloquent style, / prefer the uselessness of pagan guile / to the usefulness of Sacred Scripture. There are also others, who, devoted to sacred reading and scorning the works of other pagans, yet frequently read Terence's fiction, / and as they delight in the sweetness of his style and diction, / they are stained by the learning of wicked things in his depiction. / Therefore I, the Strong Voice of Gandersheim, have not refused to imitate him in writing / whom others laud in reading, / so that in that selfsame form of composition in which the shameless acts of lascivious women were phrased / the laudable chastity of sacred virgins be praised / within the limits of my little talent. ${ }^{23}$

Particularly important, as other scholars have shown, is Hrotsvit's naming, in the Preface to the Plays, the 2nd century вСE Roman comic playwright Terence as an earlier writer who provided the model for her plays. Terence's manuscripts may also have contributed to Hrotsvit's presentation of herself in her prefaces, since Terence introduces each of his plays with a prologue in which he addresses his audience-which seems to be imagined as both a reading audience and an audience in a theater. ${ }^{24}$ In his very influential chapter "Hrotsvitha," Peter Dronke suggests that the

\footnotetext{
22 See Wilson, Ethics, pp. 5, 7 .

23 Wilson, Plays, p. 3; Plures inveniuntur catholici cuius nos penitus expurgare nequimus facti - qui pro cultioris facundia sermonis · gentilium vanitatem librorum utilitati praeferunt sacrarum scripturarum - Sunt etiam alii sacris inherentes paginis - qui licet alia gentilium spernant · Terentii tamen fingmenta frequentius lectitant · et dum dulcedine sermonis delectantur · nefandarum notitia rerum maculantur • Unde ego Clamor Validus Gandeshemensis · non recusavi illum imitari dictando $\cdot$ dum alii colunt legendo $\cdot$ quo eodem dictationis genere $\cdot$ quo turpia lascivarum incesta feminarum recitabantur $\cdot$ laudabilis sacrarum castimonia virginum iuxta mei facultatem ingenioli celebraretur, p. 132, lines 1-13.

24 See Florence Newman's "Strong Voice(s) of Hrotsvit," in this volume. Some of Terence's prologues specify that the text was spoken by the producer and leading actor of Terence's plays as part of the performance.
} 
opening statement, cited above, is bound to be untrue in any literal sense, "at least a wild exaggeration, and almost certainly a joke," because few Catholics would have "had the knowledge to discriminate among styles in this way." 25 Yet, more than 600 Terence manuscripts survive, many of them including annotated versions of all six of his plays and their prologues (with commentary dating back to Donatus, one of Jerome's teachers in the 4th century). It seems likely, therefore, that Hrotsvit has been drawn to the "eloquent style" of Terence and other pagan authors and that she and at least one of her teachers did have the knowledge to discriminate among styles.

A number of critics have noted that the way Hrotsvit names herself in the Preface to the Plays invites a comparison to John the Baptist. After announcing that she will imitate Terence's Roman comedies but substitute praise for the chastity of sacred virgins where Terence depicts the "shameless acts of lascivious women," she names herself "Clamor Validus Gandeshemensis," Mighty Voice, or Cry, [Hrotsvit] of Gandersheim, giving the Latin translation of her Saxon name. By naming herself thus, Hrotsvit makes, in Wilson's words, "a programmatic statement of her authorial intent, aligning herself with John the Baptist (vox clamantis), the patron of Gandersheim Abbey." ${ }^{26}$ Hrotsvit also identifies herself as Precursor of Christ, like John the Baptist. Although Hrotsvit lives after both John and Christ, her writings allow her to go before Christ, as did John, beginning her religious poems with the life of Mary, and, like John, to point the way to Christ. There may also be in Hrotsvit's choice of words an echo of Hebrews 5:7, where Christ is described as offering up prayers and supplications "with a strong cry," "in the days of his flesh." ${ }^{27}$ The New Oxford Annotated Bible suggests that in this passage, "Jesus' agonizing prayer in Gethsemane (Mark 14:32-42) was heard in the sense that he learned obedience by submitting to the divine will, which involved death and resurrection." Throughout her prose addresses to readers, as well as her poems and plays, Hrotsvit, with her "strong cry," provides readers with multiple examples of the value of conversion, or submission to the divine will.

25 Dronke, "Hrotsvitha," p. 70.

26 Wilson, Florilegium, p. 41, n. 2.

27 See Berschin, Opera, vii, n. 2. In the Douay-Rheims translation, the full verse is "Who [Christ] in the days of his flesh, with a strong cry and tears, offering up prayers and supplications to him that was able to save him from death, was heard for his reverence"; "qui in diebus carnis suae preces supplicationesque ad eum qui possit salvum illum a morte facere cum clamore valido et lacrimis offerens," Biblia Sacra Vulgata (Stuttgart, 1983). 
Hrotsvit goes on to justify her decision to imitate and rewrite Terence's plays: she had to "contemplate and give a rendition / of that detestable madness of unlawful lovers and of their evil flattery" to fulfill her intent because:

the more seductive the unlawful flatteries of those who have lost their sense, / the greater the heavenly Helper's munificence / and the more glorious the victories of triumphant innocence are shown to be, / especially / when female weakness triumphs in conclusion. / And male strength succumbs in confusion. ${ }^{28}$

This description not only applies to many female characters in her plays but also applies to the potential triumph of her writing over male criticism. ${ }^{29}$ She then concedes that her style is inferior to Terence's but says to her critics that she is not "so vain / that in order to avoid censure I would refrain / from preaching Christ's glory and strength as it works through His saints to the extent He grants me the ability to do so." ${ }^{30}$ Although, as Alan Thacker has pointed out, the Venerable Bede "envisaged women preachers," "preaching Christ's glory" is a remarkable activity for a woman in the Middle Ages, even more remarkable, perhaps, than triumphing over male criticism.

Nevertheless, Hrotsvit does present herself not only as preaching Christ's glory but also as enacting-and encouraging all her readers to enact - the apostolic ideal made explicit in her second poem, Ascensio. Hrotsvit goes on to address the hypothetical charge of presumption, discussed earlier in this chapter, and concludes by saying she will rejoice if her "devotio" pleases anyone. Wilson translates devotio as "pious gift." Dronke translates it "labour of love." Literally, the word denotes a consecrating or devoting, but in Christian writers it generally means "piety," "devotion," or "zeal," according to Lewis and Short. ${ }^{31}$ In Hrotsvit's Preface to the Plays, then, her devotion - in the form of her writings - may please readers. But she concludes that the act of writing has pleased her even if no one else is pleased.

28 Wilson, Plays, p. 3; quia quanto blandicię amentium ad illiciendum promptiores . tanto et superni adiutoris gloria sublimior · et triumphantium victoria probatur gloriosior presertim cum feminea fragilitas vinceret - et virilis robur confusioni subiaceret, p. 132, line 20-p. 133, line 3.

29 Florence Newman makes this point in "Strong Voice(s) of Hrotsvit," in this volume.

30 Wilson, Plays, p. 4; see n. 6.

31 Charlton T. Lewis and Charles Short, A Latin Dictionary (Oxford, 1998). 
The reason Hrotsvit gives to explain why she is pleased, even if no one else is, may puzzle readers. The sentence is complex, including both the reason why readers may not be pleased and the reason why she is. Dronke translates:

If my labour of love gives pleasure to anyone, I'll be glad; but if, because of my worthlessness or the boorishness of my flawed style, it pleases no one, what I have created still gives delight to me-because, while in the other little works that spring from my ignorance, I gathered my poor efforts bound in a chaplet of heroic verse, here I have plaited them in a dramatic chain, avoiding the baleful delights of the pagans by keeping them at arm's length. ${ }^{32}$

She takes pleasure in the accomplishment. Other passages suggest that more meaning is implicit. One possibility relates to the subject matter of her sacred stories and plays. Wilson has noted the relevance of Paul's first letter to the Corinthians to a passage in the "Epistle," which may be equally relevant here. Paul writes:

And I, brethren, when I came to you, came not in loftiness of speech or of wisdom, declaring unto you the testimony of Christ... And my speech and my preaching was not in the persuasive words of human wisdom, but in shewing of the Spirit and power; That your faith might not stand on the wisdom of men, but on the power of God. ${ }^{33}$

Hrotsvit's poems and plays may be understood as parallel to the testimony of Christ that Paul declares to the Corinthians, showing the way to conversion.

The "Epistle" that follows sheds more light on Hrotsvit's pleasure in her accomplishment. A heading in the manuscript identifies this text as Hrotsvit's "letter to the learned patrons of this book."34 In the ensuing letter, Hrotsvit's name is written in full capitals. She leaves no doubt about genre, audience, or author. After expressing her gratitude that readers "profoundly nourished by the study of philosophy" have "found the little work of a worthless woman worthy of your admiration," Hrotsvit equates their

32 Dronke, p. 69; Si enim alicui placet mea devotio $\cdot$ gaudebo $\cdot$ si autem $\cdot$ vel pro mei abiectione vel pro vitiosi sermonis rusticitate nulli placet · memet ipsam tamen iuvat quod feci · quia dum proprii vilitatem laboris in aliis meę inscientię opusculis heroico ligatam strophio $\cdot$ in hoc dramatica vinctam serie colo $\cdot$ perniciosas gentilium delicias abstinendo devito, p. 133, lines 16-22.

331 Cor. 2:1, 4-5, Douay-Rheims version.

34 Wilson, Plays, p. 4; EPIstola eiusdem ad quosdam sapientes huius libri fautores, p. 134 . 
encouragement of her with praise for "the Giver of grace, which is working through me." 35 Wilson points out that this letter "abounds in humility formulae and in the traditional proemium topoi intended to secure the listener's goodwill," with "praise of the addressees embedded in selfdeprecatory phrases of humility." 36 Consistently, however, the vocabulary and rhetoric belie the declarations of inadequacy or rusticity. Dronke notes, “Hrotsvitha 'demonstrates' her ignorance by using deliberately recherché language - the Greek philosophical expressions per dynamin...per energian - that she will have drawn from a letter by St Jerome." 37 The very language Hrotsvit uses to express inadequacy functions instead as evidence of her rhetorical skill.

At the same time, Hrotsvit always insists that her skill is a gift from God. As in the Preface to the Plays, where Hrotsvit emphasizes her responsibility to use the gifts God has granted her to preach Christ's glory and strength, in this letter she also depicts her art as a gracious gift from God. After describing her lack of confidence in her ability before she received encouragement from the men her letter addresses, Hrotsvit writes:

But now, since the testimony of three is said to constitute truth, invigorated by your judgment I will presume to continue my works / trusting in God and with His permission and to submit it to the examination of learned clerks. / I am torn between two contradictory emotions: joy and fear; I rejoice with all my heart / that God, by whose grace alone I am what I am, is praised in my art; / but I also fear to appear to be more than what I am. I am convinced that both would be wrong: to deny God's gracious gift to one; / and to pretend to have received a gift when one has received none. /

I do not deny that by the gift of the Creator's grace I am able to grasp certain concepts concerning the arts because I am a creature capable of learning, / but I also know that through my own powers, I know nothing. ${ }^{38}$

35 Wilson, Plays, p. 4; quia cum philosophicis adprime studiis enutriti · et scientia longe excellentius sitis perfecti - mei opusculum vilis muliercule $\cdot$ vestra admiratione dignum duxistis - et largitorem in me operantis gratię fraterno affectu gratulantes laudastis ·, p. 134, lines 8-15.

36 Wilson, Ethics, p. 7 .

37 Dronke, "Hrotsvitha," p. 74.

38 Wilson, Plays, p. 5; At nunc quia trium testimonium constat esse verum - vestris corroborata sentenciis fiducialius praesumo et componendis operam dare si quando deus annuerit posse - et quorumcumque sapientium examen subire - Inter hęc diversis affectibus gaudio videlicet et metu in diversum trahor - Deum namque cuius solummodo gratia sum id quod sum in me laudari cordetenus gaudeo $\cdot$ sed maior quam sim videri timeo • quia utrumque nefas esse non ambigo et gratuitum dei donum negare · et non acceptum accepisse simulare - Unde non denego praestante gratia creatoris per dynamin me artes scire - quia sum animal capax discipline - sed per energian fateor omnino nescire, p. 134, line 22-p. 135, lines 8. 
Dronke notes that Hrotsvit "gives her patrons a biblical auctoritas, from Deuteronomy 19:15" when she writes " what is confirmed by three witnesses is true' " and "adapts to herself the words that Paul had used (1 Cor. 15:10): 'by the grace of God I am what I am.' "39 Both of these attributions contribute to an overall effect of the letter, to advance Hrotsvit's theme of conversion.

Toward the end of the "Epistle," Hrotsvit returns to the idea that she must use her talents to praise God:

In order to prevent God's gift in me from dying by my neglect, I have tried whenever I could probe, / to rip small patches from Philosophy's robe / and weave them into this little work of mine, / so that the worthlessness of my own ignorance may be ennobled by their interweaving of this nobler material's shine, / and that, thus, the Giver of my talent all the more justly be praised through me, / the more limited the female intellect is believed to be. ${ }^{40}$

The reference to ripping patches from Philosophy's robe exemplifies the complexity of Hrotsvit's depiction of herself. Multiple Boethian echoes and references throughout her works make it clear she would know that in the first prose section of Book I in the Consolation of Philosophy Boethius describes Philosophy's dress as made of "imperishable thread, of delicate workmanship," but that "violent hands had ripped this dress and torn away what bits they could." ${ }^{11}$ Dronke suggests that the details should be seen as mock-humility, when she implicitly compares herself to "skirmishing sects of pseudo-philosophers, men who thereby degraded Philosophia, grabbing at her dress as if she were a meretrix." ${ }^{2}$ Unlike the pseudo-philosophers, Hrotsvit "interweaves this nobler material's shine," to praise God, who has given her the talent she uses to create her "little work." Dronke concludes, "In the very moment she plays upon the chimera of women's intellectual inferiority, Hrotsvitha reminds her sages that philosophers have always been inspired by Philosophia, she who could be called 'womanly understanding' incarnate." 43

39 Dronke, "Hrotsvitha," p. 74.

40 Wilson, Plays, p. 5; Quapropter ne in me donum dei annullaretur ob neglegentiam mei · si qua forte fila vel etiam floccos de panniculis a veste Philosophię abruptis evellere quivi · praefato opusculo inserere curavi · quo vilitas meę inscientię intermixtione nobilioris materiae illustraretur · et largitor ingenii · tanto amplius in me iure laudaretur . quanto muliebris sensus tardior esse creditor, p. 135, lines 12-18.

41 S.J. Tester, trans., The Consolation of Philosophy (Cambridge, Mass., 1978), pp. 133-35.

42 Dronke, "Hrotsvitha," p. 75.

43 Dronke, "Hrotsvitha," p. 75. 
Wilson notes a shift of emphasis in the "Epistle" and the Preface to the Plays, "from Christ's mandate to spread his ideas (Mark 3:14-15; Matt. 28:16-20) clothed in the parable of the talents and Hrotsvit's insistence that it is God's gift of grace infusing the artist which makes his or her work persuasive, to the concern-Pauline in its formulation-that the welfare of the hearer or reader is much more important than the success of the speaker." 44 God's gift to Hrotsvit is the skill to praise God in ways that encourage Christians to turn toward God rather than away from him. As early as the First Preface, Hrotsvit subtly shifted the emphasis away from her supposed inadequacies to what she had managed to accomplish without help beyond "heavenly grace's aid" and to the significance of the result: song "in the dactylic mode" and divine praise from an instrument of "some utility." In the two prose texts introducing the plays she is more explicit about her desire to write, the pleasure she takes in the act of writing and the "devotio" she has created, and, in Wilson's words, "her Christian responsibility to praise the Lord and preach his salvation." 45

The preface to the Gesta receives critical attention for somewhat different reasons but also provides both biographical information and evidence of Hrotsvit's rhetorical skill. In the best known passage from this preface, Hrotsvit dramatizes the difficulties she faced in writing about the achievements of the emperor Otto I with a beautiful epic simile:

I was like a stranger wandering without a guide through the depth of an unknown forest where every path was covered over and mantled with heavy snow. In vain he tries to follow the directions of those who are showing the way only by a nod. Now he wanders through pathless ways, now by chance he comes upon the trail of the right path, until at length, when he has traversed half of the thick-treed domain, he attains the place of long sought rest. There staying his step, he dares not proceed farther, until either he is led on by someone overtaking him or follows the footsteps of one who has preceded him. In like manner, I, bidden to undertake a complete chronicle of illustrious achievements, have gone on my way stumbling and hesitating, so great was the difficulty of finding a path in the forest of these royal deeds. ${ }^{46}$

44 Wilson, Ethics, pp. 7-8.

45 Wilson, Ethics, p. 8.

46 Gesta, p. 39; sed veluti si aliquis nescius - ignoti per latitudinem saltus esset iturus · ubi omnis semita nivali densitate velaretur obducta $\cdot$ hicque nullo duce $\cdot$ sed solo pręmonstrantium nutu inductus · nunc per devia erraret · nunc recti tramitem callis inprovise incurreret · donec tandem emensa arboreę medietate spissitudinis · locum optatę comprehenderet quietis · illicque gradum figens ulterius progredi non presumeret · usque dum vel alio superveniente induceretur · vel precedentis vestigia subsequeretur · haut aliter 
As a poet and a Christian, Hrotsvit has been unsure which way to turn as she accomplished the difficult task imposed on her by her abbess. However, she presents herself as an actor, making choices. In a sense she dramatizes her role as author; although Gerberga has no speaking role within the text, through her evaluation of the Gesta (along with the archbishop's) she has clearly been an active player, who authorized the inclusion of the prose introduction and the Gesta in Hrotsvit's book.

It is not clear to me why Hrotsvit chose to reverse what seems to be an incipient pattern in Books One and Two, in which she addresses Gerberga with poetry and other readers with prose, to address Gerberga here in prose. One effect is to link the more particular reader, teacher, and patron, Gerberga, more closely with the non-specific reader of the First Preface and the Preface to the Plays. I will say more about this in the discussion of the poetic addresses below.

\section{The Poetic Addresses}

As noted earlier, Hrotsvit's poetic addresses to readers work with the prose addresses to convey information about Hrotsvit's sense of herself as an author and contribute to the overarching themes of conversion and Christian responsibility. The 12-line poem in elegiac distichs addressed to Gerberga, placed immediately after the First Preface, reiterates Hrotsvit's admiration and Gerberga's royal status and learning. Dronke notes that two lines in this poem might guide a reader's response to Hrotsvit's description of her poems as crude verses (incultos...stichos): "When you are weary, after your varied labours, / deign to read these songs by way of play." He concludes, "If reading Hrotsvitha's verses is to be relaxing (ludens) for Gerberga, the task of refining them (purgare) cannot be meant too strenuously." 47 One possible implication is that the vocation of nun (or abbess) and writer need not be all suffering and martyrdom; it can be joyful and playful.

Hrotsvit's briefer address to Gerberga, between the end of Theophilus and the beginning of Basilius, and the ten-line address to readers in the

ego magnificarum - prolixitatem rerum iussa ingredi · regalium multiplicitatem gestorum nutando et vacillando egerrime transcurri - hisque admodum lassata competenti . in loco pausando silesco - nec augustalis proceritatem excellentiae sine ducatu appono subire, p. 271, line $15-$ p. 272 , line 9.

47 Dronke's translation, "Hrotsvitha," p. 67; Quam doctrina tua instruit egregia, / Et, cum sis certe vario lassata labore, / Ludens dignare hos modulos legere," p. 3, lines 6-8. 
same verse form that follows immediately afterward, on the same manuscript page, continue themes introduced in the First Preface and developed in the sacred stories. Although Hrotsvit continues to refer to her poems as crude (here vitiosi rather than incultos), the tone seems different. Hrotsvit tells Gerberga that she sings joyfully about a wretched sinner who won loving forgiveness. The little poem reiterates that Hrotsvit uses her gifts to praise God and to encourage her readers to follow her example: "do not choose to spurn these, even though they be exceedingly crude (vitiosi), but do thou praise with gentle heart the works of God."48

The adjective vitiosi opens up further complexity. The noun vitium has a semantic range including "fault," "defect," "blemish," "imperfection," and "vice," the English word that developed from vitium. Significantly vitium was (and is) used to name grammatical, rhetorical, and moral vices or faults. Donatus' discussions of grammatical and rhetorical faults were standard texts throughout the Middle Ages. However, Gregory the Great complicated an understanding of grammatical and moral vice with a paradox. ${ }^{49}$ For example, in the Preface to his Moralia in Job, Gregory explains:

And hence that art of speaking itself, which is conveyed by rules of worldly training, I have despised to observe; for as the tenor of this Epistle also will tell, I do not escape the collisions of metacism, nor do I avoid the confusion of barbarisms, and I slight the observing of situations and arrangements, and the cases of prepositions; for I account it very far from meet to submit the words of the divine Oracle to the rules of Donatus. For neither are these observed by any of the translators thereof, in the authoritative text of Holy Writ. Now as my exposition takes its origin from thence, it is plainly meet that this production, like a kind of offspring, should wear the likeness of its mother. ${ }^{50}$

As G.R. Evans explains in The Thought of Gregory the Great, "Because it is trying to do something which is impossible for human language, our speech is obliged to break its own rules in speaking of God." She goes on, "As Bede puts it, "it neglects the rule of grammatical disposition so as to sing of the glory of the holy and undivided Trinity in a clear voice.' "51 Thus

\footnotetext{
48 Wiegand, p. 193; Spernere quos noli, nimium cum sint vitiosi, / Sed lauda miti pectore facta dei!, p. 94, lines $5^{-6 .}$

49 It is nearly obligatory to use different English words to distinguish between the grammatical and moral meanings of vitium. However, Gregory's and Hrotsvit's uses the word suggest both meanings simultaneously.

50 Epistle V: http://www.lectionarycentral.com/GregoryMoralia/Epistle.html.

51 G.R. Evans, The Thought of Gregory the Great (Cambridge, 1986), p. 37.
} 
the grammatical and rhetorical correctness and beauty of pagan writers could communicate moral vice (as in Terence's comedies), and inversely biblical grammatical and rhetorical faults could communicate moral virtue. Here Hrotsvit calls her dactylic strains vitiosi, marked by great grammatical or rhetorical fault, but insists they teach-even preach-moral virtue. Also relevant is the fact that Gregory does not actually break the grammatical rules; he only says he does. Similarly, Hrotsvit's Latin is polished and rhetorically effective.

The poetic address to readers that follows the Second Address to Gerberga is explicit about how the narrative poem it introduces should be read and what readers should learn from the hagiographic example:

He who wishes to hear an unfailing example of pardon and of the bounteous gifts of the great goodness of God, let him peruse with humble heart these lines; nor let him despise the frail sex of a weak woman, who with frail pen has composed these measures; but rather let him praise the heavenly goodness of Christ, Who does not will to destroy sinners by the punishment they deserve, but rather to convert them and bring them back to eternal Life; with joy will every man rejoice, whoever, upon examining the present account, will acknowledge the truth of what I say. ${ }^{52}$

The theme of conversion is explicit, especially the power of grace to bring back to God those Christians who have turned away from Him.

Hrotsvit also addresses Otto I and Otto II in poems placed between the prose address to Gerberga and the beginning of the Gesta. Both poems are replete with rhetorical topoi typical of dedicatory verse. Wilson notes that they "follow the same dedicatory structure as seen in the Epistle, beginning with praise for the addressee and self-deprecatory formulae, usually of the feminei sexu type." ${ }^{33}$ Hrotsvit repeats that she has not been motivated by presumption. Although most of Hrotsvit's prefatory addresses seem carefully constructed to shape readers' responses to her authorship and to her message, the prose address to Gerberga and the two poems to the father and son sovereigns indicate that the challenges posed by the Gesta are different and more difficult. Wailes notes the absence of any religious invocation or prayer and suggests all three texts that introduce

52 Wiegand, p. 193; Qui velit exemplum veniae comprendere certum / Necnon larga dei pietatis munera magni, / Pectore versiculos submisso perlegat istos / Nec fragilem vilis sexum spernat mulieris, / Quę fragili modulos calamo cantaverat istos, / Sed mage cęlestem Christi laudet pietatem, / Qui non vult digna peccantes perdere poena, / Sed plus perpetuę conversos reddere vitę: / Gaudens gaudebit; quod verum stare probabit, / Quisquis praesentem perscrutatur rationem, p. 94, lines 7-16.

53 Wilson, Ethics, p. 8. 
the Gesta provide evidence that this writing task was distasteful to Hrotsvit and exhibit "a carefully disciplined reluctance to write as directed." Jay T. Lees suggests that each reader specifically addressed likely received only the personalized introduction to the Gesta, ${ }^{55}$ while readers of the manuscript (and later editions) — who have less control over Hrotsvit and her writings - are privy to all three. Thus, one purpose of the addresses to Gerberga and the two Ottos is to increase the likelihood that the Gesta will be approved and thus be eligible for inclusion in the manuscript of Hrotsvit's writings.

Including all three in the manuscript is an eloquent testimony to her success and provides readers with a particularly complex context within which to understand the narration that follows. Scholars are increasingly considering whether the themes and purposes of the Gesta overlap with those of the earlier poems and plays and include teaching, if not preaching, about conversion. Wailes suggests Hrotsvit's presentation of Otto's deeds invites comparison of the Holy Roman Emperor with the pagan emperors depicted in the hagiographic poems and plays:

In Dionysius, Hrotsvit had modeled the right relationship between the pope and a soldier of Christ, for the pope directed Dionysius (the miles Christi) to go forth into Gaul and to subjugate its people to the faith. The Gesta breaks off at the point where Hrotsvit would have been forced to glorify a perversion of this relationship. Otto's treatment of the papacy betrayed more than a little libido dominandi, in Augustine's phrase, and placed his rule more nearly within the civitas saeculi than the civitas Dei. It was consistent with her faith for Hrotsvit to find in Otto's kingship the qualities of an ideal Christian ruler, which she did, but she could not assert such qualities in his rule as emperor. Hence she declared herself snowbound and ended her poem. ${ }^{56}$

As with her other works, the addresses to these very specific readers provide guidance on how to read the poem and suggest that the reading of her books, like her writing of them, is part of an apostolic mission involving choices for both author and reader that relate to conversion broadly construed.

The brief poem addressing readers of the Primordia is similar in content to the prose arguments, or plot summaries, that precede each of the plays. However, Lees notes details that suggest the Primordia can be read

\footnotetext{
54 Wailes, Spirituality, pp. 207 and 205-06.

55 See Jay T. Lees, "David rex fidelis?" in this volume.

56 Wailes, Spirituality, p. 214.
} 
as a continuation of the Gesta. ${ }^{57}$ Particularly notable in this context is Hrotsvit's naming Duke Otto, Otto I's grandfather, in the prefatory poem as responsible for completing the establishment of Gandersheim. Lees argues that Hrotsvit's decision about where to end the Primordia "has much to do with her effort to show Otto I the error of his ways in his treatment of Gandersheim." 58

\section{The Authorial Insertions}

In addition to addressing her readers in prose prefaces and dedicatory poems, Hrotsvit often inserts into her third-person narratives direct addresses in the first-person, sometimes addressing God or a character in her poem, sometimes addressing her readers. One of the main functions of these insertions is to model the prayers and hymns of praise which Hrotsvit insists are the happy obligation of Christians who willingly turn toward God. A second function is to bring readers into the present, thus emphasizing that Christ's life and the apostolic mission he bequeathed to "his cherished friends" are not only historical events but more significantly realities in the present for all Christians. These two functions are related, since characters in the poems and prayers often pray and sing hymns of praise very similar to the ones in Hrotsvit's voice.

The authorial insertions sometimes contribute to the theme of conversion more directly. For example, in the prayer to Mary that introduces Maria, Hrotsvit is even more specific about using her talents to praise God than she had been in the First Preface. She prays:

Do thou graciously deign to assist the prayers and new little songs of thy handmaiden Hrotsvitha, who with zeal ministering to my womanly muse, do now suppliantly sing in dactylic measures, desiring to touch, if ever so lightly, upon a tiny portion of the praise which is thine, and to celebrate the bright beginnings of thy blessed origin and also thy royal child. ${ }^{59}$

Hrotsvit asks Mary to assist her as she sings Mary's praise in the poem that follows. After specifying that no one can adequately praise Mary, "who

57 Lees, "David rex fidelis?" in this volume.

58 Lees, "David rex fidelis?" in this volume.

59 Wiegand, p. 15; Tu dignare tuę famule clementer adesse / Hrotsvithę votis carminulisque novis, / Quę tibi femineę studio famulante camene / Iam supplex modulis succino dactilicis / Exoptans vel summatim attingere saltim / Laudis particulam, virgo, tue minimam / Ortus atque tui primordia clara beati / Necnon regalem pangere progeniem, p. 4, lines $17-24$. 
shinest far beyond the praises of the angels," because she carried Jesus in her womb, she goes on to say:

$\mathrm{He}$, if it please Him, is able to loose the strings of my tongue and to touch my heart with the dew of His grace. And thus assisted by the gift of His tender kindness, I will render thanks to Him, and sing thee also, O Virgin, lest I be condemned - and rightly so-as a companion to those ungrateful and slothful servants who neglect to send according to their ability praise to the Most High throned; but rather may I merit to be united to the choirs of virgins and to praise eternally the crimson Lamb of God. ${ }^{60}$

These lines may echo Revelation 14, in which case, the "new little songs" of the handmaiden Hrotsvit join those of the 144,000 virgins who have been redeemed and are able to learn a new song to sing before the Lamb on mount Zion. At the very least, these lines explicitly link Hrotsvit's activities as a poet to earning the right to sing Christ's praises eternally-if it pleases God to touch her heart with the dew of grace. This prayer also may adumbrate the idea suggested in the Preface to the Plays that Hrotsvit is like the apostles and like John the Baptist. Like the apostles, she is a "bearer" of Christ in the world and to the world by writing in the present about the gift of grace for all mankind; like John the Baptist she is a precursor when she tells the story of Mary's life leading up to the incarnation.

The lengthy address to Christ with which Maria concludes, in which Hrotsvit praises the grandeur of Christ's power, conveys a similar sense of Hrotsvit's role as a "bearer" of Christ in the present. This speech begins in the third-person but modulates into series of statements in the second-person. Although it can be read in Hrotsvit's voice, as the absence of quotation marks in modern editions suggests, it also can be read as an expression of the new wisdom Aphrodisius, the ruler of Sotines who converted to Christianity at the end of Maria, has gained from his encounter with the baby Jesus in the temple. When the hymn of praise concludes with "through Whom all heavenly gifts are granted to us!"61 there is a sense of inclusiveness - the hymn may be in the voice of Aphrodisius or of Hrotsvit but it expresses the gratitude of all Christians for their redemption and the heavenly grace ("gifts" in Wiegand's translation) granted to them.

60 Wiegand, p. 15; Si placet, ipse meam potis est dissolvere linguam / Et cor rore suę tangere gratiolę / Quo prestante suę mitis dono pietatis / Grata sibi pangam, te quoque, virgo, canam, / Ne comes ingratis condampner iure pigellis, / Quos piget altithrono psallere pro modulo, / Sed mage purpureum laudare perenniter agnum / Promerear turmis addita virgineis, p. 5 , lines $37-44$.

61 Wiegand, p. 65; Gracia caelestis per quem conceditur omnis!, p. 35, lines 897. 
Six lines of poetry follow, in the first-person singular: "What gifts shall I render now to the Creator, worthy of all the good He hath bestowed upon me, Who graciously in His wonted goodness hath permitted me, an unworthy servant, to render thanks, however feeble? For this, may the angelic hosts, I pray, unceasingly praise the Lord." 62 An echo of Psalm 116.12 (Vulgate 115.12), "What shall I render to the Lord, for all the things that he hath rendered to me?" is likely significant. The Psalm answers, "I will take the chalice of salvation; and I will call upon the name of the Lord. / I will pay my vows to the Lord before all his people: / precious in the sight of the Lord is the death of his saints. / O Lord, for I am thy servant: I am thy servant, and the son of thy handmaid. Thou hast broken my bonds." 63 Hrotsvit, servant and handmaid of the Lord, likewise pays her vows before all the people and demonstrates throughout her writings how precious in the sight of the Lord is the death of his saints.

The Munich manuscript places this rhetorical question and prayer on a page otherwise entirely devoted to the title of Ascensio, in large capitals, with line breaks and abbreviations as follows:

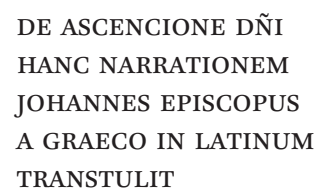

Manuscript placement suggests that the brief address, while clearly transitional, points forward to Ascensio more than back to Maria. Indeed the very ending of Maria points ahead to Christ's life and death and the gift of redemption that resulted from his incarnation, suffering, and return to God. Even the manuscript layout contributes to the idea that Hrotsvit, like John the Baptist, is a precursor of Christ. Certainly the authorial insertion serves to remind readers of the relevance of the narrative and its themes to the author and all other Christians in the present. The space and detail specifying the sources, apocryphal though they are, confirm a sense

62 Wiegand, p. 65; Qualia retribuam factori munera nunc iam / Pro cunctis digne, mihimet quę reddidit ipse, / Qui pius indignam solita pietate famellam / Me, licet exiles, fecit persolvere grates? / His super angelicę celorum, posco, caterve / Collaudare deum non cessent sedulo verum, p. 35, lines 898-903.

63 Douay-Rheims translation; quid retribuam Domino pro omnibus quae retribuit mihi / calicem salutaris accipiam et nomen Domini invocabo / vota mea Domino reddam coram omni populo eius / pretiosa in conspectus Domini mors sanctorum eius / o Domine quia ego servus tuus ego servus tuus et filius ancillae tuae disrupisti vincula mea, Ps. 115.13-16: Biblia Sacra Vulgata. 
conveyed in the prose prefaces that Hrotsvit is confident about her responsibilities as a Christian and about her choices as an author.

Another short poem placed between Ascensio and Gongolfus functions similarly. It explicitly invites readers to pray to the "Gentle King" that Hrotsvit "may with grace from heaven continue to sing Thy divine praises, who in verse has set forth Thy marvels." ${ }^{4}$ Hrotsvit's reference to the "pitying heart" of her readers serves as a reminder of the rhetorical stance she adopts in her prose prefaces. The reference to "poor Hrotsvitha," who requests the pitying intercession of her readers and God's mercy_that he "spare her"-may suggest the difficulty of writing her poems. Their completion, she tells us, gives her joy; the writing of them may have caused some suffering.

Hrotsvit's prose and poetic addresses to her readers- whether brief or otherwise-all contribute to the overarching theme of conversion, often by reminding readers of the relevance of the apostolic mission enacted in the past to the lives and choices of her readers in the present and in the future. As Linda McMillin demonstrates in "The Audiences of Hrotsvit" in this volume, Hrotsvit's call to conversion and service is addressed to multiple audiences, especially the canonesses at Gandersheim and the Ottonian court. This has, among other things, a leveling effect. Rather than turn in particular to ecclesiastical or political leaders, she conveys time and again that the responsibility for words and deeds aligned with Christian values rests in each Christian, whatever his or her rank or role in society. Even when she addresses Gerberga, Otto I, and Otto II, among her highest ranking contemporaries, their responsibility is virtually the same as that of the lowliest Christian, such as the servant in Basilius, who sells his soul to the devil in order to win the love of the daughter of his master. The exception is that monastic and secular leaders have more power to lead others astray and may be more likely targets for demonic intervention, as illustrated in Theophilus.

\section{Other Manuscript Insertions}

Three other poems included in the Munich manuscript may also contribute to Hrotsvit's overarching purposes in her collection of writings. The

\footnotetext{
64 Wiegand, p. 83; Haec quicumque legat, miseranti pectore dicat: / 'Rex pie, Hrotsvithe parcens miserere miselle / Et fac divinis persistere caelitus odis / Hanc, quę laudando cecinit tua facta stupenda,' p. 41 , lines $147-50$.
} 
first, eight hexameters placed between the prayer with which Theophilus concludes and the Second Address to Gerberga that introduces Basilius, is often called a table blessing. While the poem is clearly a prayer, its addressee is less clear than in other prayers, and the "speaker" uses the first-person plural:

May the only Son of the Most High, begotten before all time, Who, pitying humankind, descended from the Throne of His Father and took a true human body from a Virgin, in order that He might destroy the bitter taste of that first virgin, bless devotedly for us the food of this spread table, making these viands wholesome to those who taste them. Whatever we are and whatever we taste or whatever we may do, let the Hand of the Creator, our King, bless all. ${ }^{65}$

Stephen Wailes provides an overview of scholarly comment on this prayer in "The Sacred Stories in Verse" in this volume, noting that "the question of the table blessing is important because it may define the audience for which Hrotsvit wrote; this, in turn, would set certain parameters for interpretation of the stories." I would like to suggest that in addition to reading the prayer as an indication of the level of education expected from the audience, as Wailes argues, the "food of this spread table" should be understood metaphorically, in which case the sacred stories would be the "viands wholesome to those who taste them." In that case, the poem would be a request for Christ to bless the poems and for God to bless all. Matthew 6:11 provides a potential model for the idea of food being understood metaphorically, especially in the Vulgate translation "panem nostrum supersubstantialem da nobis hodie." Herrad of Hohenbourg provides an explicit example of the metaphor of religious poetry as spiritual food in her prologue to the Hortus deliciarum, a late 12th-century collection of poems, when she writes:

I make it known to your holiness, that, like a little bee inspired by God, I collected from the various flowers of sacred Scripture and philosophic writings this book, which is called the Hortus deliciarum, and I brought it together to the praise and honor of Christ and the church and for the sake of your love as if into a single sweet honeycomb. Therefore, in this very book, you ought diligently to seek pleasing food and to refresh your exhausted world

65 Wiegand, p. 185; Unicus altithroni genitus retro tempora mundi, / Qui miserans hominis descendit $a b$ arce parentis / Et carnis veram sumpsit de virgine formam, / Virginis ut gustum prime deleret amarum, / Consecret appositę nobis pie fercula mense / Has faciendo dapes gustantibus esse salubres. / Quod sumus et quod gustamus vel quicquid agamus, / Dextera factoris benedicat cuncta regentis, p. 93, lines 1-8. 
with its honeyed dewdrops, so that, always possessed by the charms of the Bridegroom and fattened on spiritual delights, you may safely hurry over ephemeral things to possess the things that last forever in happiness and pleasure. ${ }^{66}$

Caroline Bynum's well-known book Holy Feast and Holy Fast focuses on very different elements of women's perceptions of food. However, her point that Eucharistic visions often involve women receiving God as holy food and the broader point that food was central to women's charismatic roles $^{67}$ may provide further support for the suggestion that this table blessing might, read metaphorically, be closely related to the themes of Hrotsvit's writings as a whole.

Two other poetic texts presumably address the reader, though differently from any others in the manuscript. The first, given its own manuscript page, presents eight lines of the alphabetic acrostic hymn praising Etheldreda that Bede inserted in A History of the English Church and People. Bede writes:

It seems appropriate to insert in this History an elegiac hymn in praise of virginity which I composed many years ago in honour of this same queen and bride of Christ - all the more a queen because a bride of Christ. In this I am following the example of Holy Scripture, in which the narrative is frequently interspersed with songs which are known to have been composed in verse. ${ }^{68}$

The Hrotsvit manuscript includes the lines in Bede's poem with initial letters spelling out AMEN. Above these lines, the letters D I C A T descend, thus reading from top to bottom, "dicat amen." Written along the righthand side of the page, requiring readers to turn the book to read the words is the statement, "Whoever desires to go the way of salvation," which presumably begins a sentence that ends, "say amen." 69 While it is perhaps far-fetched to suppose that the turning of the page to read the script is related to conversion, the text itself explicitly addresses conversion as it relates to salvation.

\footnotetext{
66 Translated by Fiona J. Griffiths in The Garden of Delights: Reform and Renaissance for Women in the Twelfth Century (Philadelphia, 2007), p. 233.

67 Caroline Walker Bynum, Holy Feast and Holy Fast (Berkeley, 1987), p. 233 and passim.

68 Translated by Leo Sherley-Price, A History of the English Church and People (New York, 1968), pp. 241-42.

69 My translation; Quicumque viam cupit ire salutis, p. 268. Edwin Zeydel credits Paul von Winterfeld with identifying the verses as Bedan. Von Winterfeld prints a version of the page (showing the words written with landscape orientation) in his 1902 edition of Hrotsvit's Opera, p. 199. Berschin provides a photograph of the page in his edition, p. 268.
} 
The lines excerpted from Bede's hymn focus on the heavenly rewards awaiting brides of Christ:

Ah bride of Christ, bright fame on earth is thine.

More bright in Heaven thy bridal torches shine.

Exultant hymns proclaim in glad accord:

No power henceforth may part thee from thy Lord. ${ }^{70}$

Bede's poem begins with a prayer to the "All-guiding Trinity," in which he asks for guidance as he celebrates Etheldreda's victories. The opening lines also invite the comparison of Bede's theme and poem with Vergil's theme of battle and focus on "Helen's wantonness." The poem then praises a succession of virgins, beginning with Mary, "who gav'st the whole world's Parent birth," continuing through a series of virgin saints and martyrs, to assert: "Our age at length in triumphs such as these / Partakes through ETHELDREDA's victories.” The alphabetic part of the poem concludes with details of Etheldreda's life that had been the subject of the previous chapter in A History of the English Church and People, titled "Queen Etheldreda preserves her virginity, and her body remains incorrupt in the grave."

Two parallels to Hrotsvit's writings may be significant: the invitation to compare Bede's Christian poem to writing by a pagan author, and the focus on a contemporary Christian who makes it clear that Christian triumph is possible in Bede's present as well as in the past. Although it is impossible to know whether Hrotsvit herself selected the Bede passage for inclusion in her "little book," the quotation from Bede can serve as a transition from Hrotsvit's final play, Sapientia, with its emphasis on Christian martyrdom as it relates to conversion and salvation, to the Gesta, especially if the Gesta is understood to develop the larger theme of every Christian's responsibility to act in accordance with Christ's instructions in Ascensio, as Wailes argues in Spirituality and Politics.

However, a third anomalous text intervenes between the Bede page and the Gesta: "Johannes cęlum virgo," 35 hexameters depicting scenes from the Apocalypse, beginning with a large capital but no heading at the top of the page following the Bede page. Since the Bede page is folio $129 \mathrm{v}$ and the scenes from the Apocalypse begin on 13or, they face one another. The scenes from the Apocalypse conclude on 130v, sharing the page with the beginning of the Third Address to Gerberga that introduces the Gesta. Thus the manuscript presentation suggests "Johannes cęlum virgo" may

70 Bede, History of the English Church and People, trans. Sherley-Price, p. 242. 
be more closely related to the Gesta than to the dramas. However, Dronke and others, following Hugo Kuhn, have seen the lines as a conclusion to the plays. Dronke proposes that these lines might even have been performed. ${ }^{71}$

Like the page presenting lines from Bede's hymn to Etheldreda, these scenes from the Apocalypse describe the rewards awaiting "the Eternal King's servants":

Behold, the Lamb standing here on the Mount of Zion,

And the company of virgins singing new songs.

The beast attacks the saints with all the dragon's might;

But truth has laid him low; arriving on a white steed,

He whips the ancient snake to savage Tartarus.

Behold, the books of life are held open to the dead

And, alive, they rise, freed from the chains of death.

Soon all receive their due according to their merits. ${ }^{72}$

Books of life allow the dead to rise up and receive their due. The parallel to the ending of Drusiana and Calimachus may be significant. Whereas in the play it is the prayers of John the Apostle and Drusiana that resurrect Calimachus, Drusiana, and Fortunatus, in "Johannes cęlum virgo" it is the books of life held open by the Lamb, or Christ, that resurrect the dead, freeing them from the chains of death and consigning them to the judgment due to them. Revelation 20:12-15 is more explicit than the ending of "Johannes cęlum virgo": those whose names are not written in the book of life have chosen, through their life actions, the second death, and they are cast into the pool of fire with hell and death. In a sense, the character Fortunatus provides the detail from Revelation that is excluded in "Johannes cęlum virgo."

These hexameters can be read, with the Bede page, as a summary and conclusion to Books One and Two of Hrotsvit's writings authenticated by

71 Dronke, "Hrotsvitha," p. 63.

72 Wilson, Florilegium, p. 99; Hic agnum stantem supra Syon aspice montem / Et nova virgineum modulantem cantica coetum. / Haec fera congreditur sanctis virtute draconis. / Quam prostravit equo Verax egressus in albo; / Iste ligat veterem sub Tartara seva draconem. / En vitę libri mortisque tenentur aperti, / Et surgent vivi, fuerant qui morte soluti; / Quis sua pro meritis dantur mox pręmia cunctis, p. 270, lines 28-35. Although there is scholarly consensus that these hexameters are "titles" of varying line lengths summarizing scenes from the Book of Revelation, different editors divide them differently. Homeyer identifies 14 "titles"; Berschin follows von Winterfeld's identification of 12. Wilson's translation identifies five. Von Winterfeld and Homeyer identify the passages from Revelation echoed in "Johannes cęlum virgo." 
the authority of Bede and John the Apostle's apocalyptic vision. ${ }^{73}$ Heavenly rewards await the brides of Christ, who, like Etheldreda in Bede's poem, like Mary in Maria, like multiple other examples throughout Hrotsvit's sacred stories and plays, and like Hrotsvit herself, accept the apostolic mission and serve God as they are particularly able to do. Hrotsvit's writings emphasize that every Christian must choose whether to behave in ways that will result in their names being written in the book of life. If not, they, like the pagans who oppose Christians and like the Christians who turn away from God in Hrotsvit's writings, will be cast into the pool of fire with hell and death.

The manuscript evidence that links these two texts more closely to the Gesta than to the plays may be subtly significant. Jay Lees argues, in "David rex fidelis?" in this volume and elsewhere, that the Gesta can be read as deeply critical of Otto I despite the surface praise. Perhaps these two texts point to the contrast between the canonesses at Gandersheim and Otto I (and other political and ecclesiastical leaders), whose actions may be understood to resemble those of the pagan Roman emperors and Christian sinners in Hrotsvit's writings more than they resemble those of the characters who choose always to serve God. They may serve as additional reminders - not in Hrotsvit's own voice - of the choice Otto must make to avoid being cast into the pool of fire with hell and death for all eternity.

Although the Bede page and "Johannes cęlum virgo" are not explicitly addressed to readers in Hrotsvit's own voice as are the prose and poetic texts discussed earlier in this chapter, they do contribute to the theme of conversion that permeates Books One and Two of Hrotsvit's writings. They may also substantiate other evidence that Hrotsvit aligned herself with earlier monastic reform movements, such as those supported by Bede. Helene Scheck argues that Hrotsvit did not oppose:

the Cluniac and Gorze reforms current in her own time, but rather recasts aspects of reform that suit her vision of female/male partnership in piety. In her dramas and narratives, Hrotsvit creates a specular economy in which women emerge as subjects independent of and yet active with their male counterparts. ${ }^{74}$

73 Prudentius may function as an additional authority, since Hrotsvit's learned readers were likely to be familiar with his Tituli Historiarum (Dittochaeon), which concludes with four lines summarizing parts of Revelation 4 and 5 . See Wailes's discussion in "The Sacred Stories in Verse," in this volume.

74 Scheck, Reform and Resistance, p. 168. 
Hrotsvit seems simultaneously to have accepted sexual difference (she frequently draws attention to her own female sex and the female sex of many of her protagonists), to have looked beyond any inconvenience in this life caused by sexual difference, and to insist that sexual difference is irrelevant to Christian responsibility. Inconvenience for women in this life would be amply compensated by the promise of heavenly rewards in the next life.

Hrotsvit's addresses to her audience in the first-person present her as independent but orthodox, and as calling for responsibility and action from all her readers, whether they are male or female, emperor or servant. The addresses to her audience position Hrotsvit as a precursor of Christ, like John the Baptist, and simultaneously as a Christian who has herself accepted the apostolic mission and who calls for all others to follow her example, in the present and in the future. The addresses to her audience emphasize the choice her readers have: they can turn toward God, contribute their talents to the apostolic mission Christ assigns to his disciples at the end of Ascensio, and open their hearts to the grace that is Christ's gift to all; or they can turn away from God. While the plays bring the past into the present through dialogue and dramatic action that will transform those who experience them, as Michael Zampelli argues in "The Necessity of Hrotsvit" in this volume, the prefaces and other addresses more directly specify the relevance of the theme of conversion to all her readers. 